\title{
Competing Autonomy Claims and the Changing Grammar of Global Politics
}

\author{
DIANA BRYDON
}

University of Manitoba, Winnipeg, Canada

\begin{abstract}
This article argues that contending ideas about autonomy lie behind current discourses of human rights, claims to nation-state and cultural autonomy, and democracy promotion. Globalizing processes are bringing these contested understandings of autonomy, and their often silent framing within assumptions about sovereignty, into a new prominence. Locating itself within agonistic views of autonomy and politics, the article argues that it is necessary to pay closer attention to the perspectives that feminist and postcolonial analyses bring to understanding how autonomy, community, culture, and nation are co-constructed within imaginaries, such as liberal multiculturalism, that are no longer adequate to current demands for justice. To succeed, this renewed attention needs to locate itself within an effort to rethink academic community and the research protocols and collaborative practices this community permits and legitimizes.
\end{abstract}

Este artículo sostiene que las ideas contendientes sobre la autonomía yacen detrás de las disertaciones actuales sobre los derechos humanos, las declaraciones de nación-estado y autonomía cultural y la promoción de la democracia. Los procesos de globalización están conduciendo estos entendimientos contradictorios de autonomía y sus encuadramientos generalmente silenciosos, dentro de las suposiciones sobre la soberanía, a un nuevo nivel de importancia. Este artículo que se ubica a sí mismo bajo una perspectiva ardua de autonomía y política, argumenta que es necesario poner mayor atención a las perspectivas que traen los análisis feministas y postcoloniales para entender cómo la autonomía, la comunidad, la cultura y la nación se han co-construído de manera imaginaria, tales como el multiculturalismo liberal que ya no son adecuadas para las demandas actuales de justicia. Para lograr el éxito, esta atención renovada debe situarse dentro de un esfuerzo para replantear a la comunidad académica, los protocolos de investigación y las prácticas colaborativas que esta comunidad permite y legaliza.

Correspondence Address: Diana Brydon, University of Manitoba, Room 230, St John's College, 92 Dysart Road, Winnipeg, MB, R3T 2M5, Canada. Email: brydond@cc.umanitoba.ca

ISSN 1474-7731 Print/ISSN 1474-774X Online/09/030339-14 (C) 2009 Taylor \& Francis DOI: $10.1080 / 14747730903141928$ 
本文认为在当前关于人权、民族国家和文化自治的诉求以及民主推广的讨论背后, 隐藏 着有关自治的各种竞争性观点。全球化的过程正将这些关于自治的有争议的理解以及它 们通常在主权前提下悄无声息的型构彰显出来。本文将自身置于有关自治与政治的争论 性观点之中, 认为有必要更加密切关注这样一种观点, 即女性主义及后殖民主义的分析 能够帮助理解自治、社群、文化和民族是如何在诸如多元文化论等诸多已不能满足现有 正义需求的想象中相互构建的。为了能够持续进行, 这种新的关注自身需努力重新思考 学术界及其所允许和认同的研究议定书及合作实践。

Keywords: culture, feminism, postcolonialism, human rights, democracy, community, nation

... the grammar of argument has altered... it is not only the substance of justice, but also the frame, which is in dispute (Fraser, 2007, p. 170)

Although the evolution of cosmopolitan norms of justice is a tremendous development, the relationship between the spread of cosmopolitan norms and democratic self-determination is fraught, both theoretically and politically. How can the will of democratic majorities be reconciled with norms of cosmopolitan justice? (Benhabib, 2006, p. 17)

This article argues that autonomy, like sovereignty in Robert Jackson's analysis of 'Sovereignty in World Politics', is 'a basic element of the grammar of politics' (Jackson, 1999, p. 431) which is under stress today. Sovereignty and autonomy are associated but not to be confused. Elsewhere in this special issue, Louis Pauly argues that increasingly states are choosing to pool their sovereignty in order to exercise it more effectively in changing conditions. Unlike sovereignty, autonomy is not an institution but rather a foundational if disputed value and practice. Insofar as autonomy necessarily signals separateness, it might seem to be on a collision course with globalization's interconnectedness. But must autonomy be conceived in such a way? This article surveys the current state of thinking on this question to argue that globalization studies needs to attend more carefully to how the relations constituting autonomy, community, culture, and the nation-state, in the shadow of sovereignty's silent framing, are understood in changing times. Together, these interrelated concepts constitute the 'frame' for arguments about justice, a frame Nancy Fraser (2007) argues, in the epigraph above, is currently in dispute. To aid that renewed critical attention, it will be necessary to look more closely at the assumptions behind currently fashionable theories of social cohesion and of culture clash as well as theories of humanitarian intervention and multiculturalism. While this article cannot unpack each of these powerful concepts here, it argues that they function as interlocking ideas in the current global imaginary in ways that make it difficult to imagine viable alternatives to the current world order. Different understandings of individual and collective autonomy generate different prescriptions for managing intercultural and international relations.

This article speculates that if autonomy is what is at stake in different views of justice, then renewed attention to competing autonomy claims might aid in clarifying current arguments about cosmopolitanism and democracy. I hypothesize that contending ideas about autonomy lie behind current discourses of human rights, claims to nation-state and cultural autonomy, and democracy promotion. Understanding these discourses requires prior attention to assumptions about the nature and relations of autonomy, community, culture, and ethnicity on which they rely. Based on my review of current debates about these concepts, my argument then turns to Will Kymlicka's (2007) concept of liberal multiculturalism as a widely accepted but 
problematic way to address collective autonomy claims in globalizing contexts. I argue that his solution is not fully successful in taking account of shifting contexts of culture, autonomy, and community under contemporary globalization, in part because of its failure to address sufficiently the critiques launched by feminist, anti-racist, and postcolonial thinking on these issues. The autonomy of disciplinary practices and ways of seeing is also part of the frame that seems increasingly inadequate today.

The quotations that head this article address the changing contexts in which discussion of globalization and autonomy are now taking place. Once, as Seyla Benhabib (2006) implies, the autonomous will of democratic majorities within a nation-state might have ensured some semblance of legitimacy. With the rise of global cosmopolitan norms, on the one hand, however, and the rise of indigenous claims to forms of self-determination appropriate to a people but not necessarily a state, on the other, such a straightforward understanding of the justifying force of democratic self-determination no longer always suffices. Instead, as Nancy Fraser (2007) intimates, the frames, philosophical and institutional, through which national and international communities once recognized justice, are themselves now being thrown into question. A new 'grammar' is emerging. This recognition is taking place across the disciplines. The challenge for globalization scholars is to chart this emerging 'grammar of argument', in which alternative routes in the search for justice may be more appropriately re-articulated. Meeting these challenges is likely to require more collaborative, interdisciplinary, and international investigations, in which, I argue, such emergent frames as Bonnie Honig's notion of 'agonistic cosmopolitics' (2006, p. 117) or what Bert van den Brink describes as the 'non-agreement-based agonistic view' (2005, p. 257) of political autonomy would need to be considered. These processual metaphors of contention, albeit framed by a rule-based structure, may implicitly challenge some of the assumptions built into the metaphor of a normative grammar.

My argument stems from work conducted with the Globalization and Autonomy project over the last eight years. This project set out to investigate the many ways in which globalizing processes were affecting autonomy, either putting efforts to exercise autonomy under stress, given an increasingly interconnected world, as conventional wisdom seemed to suggest, or alternatively, enabling particular autonomy claims to gain more purchase as their circumstances changed. What we discovered about globalization's impact varied with the focus of our case studies and the specific definitions of autonomy each privileged. The more deeply we engaged with this topic, the more complex autonomy revealed itself to be.

In particular, notions of autonomy as self-government, the act of giving laws to oneself, exist in tension with notions of autonomy as indicating a bounded separateness or negative freedom from external influences. These definitions operate at both individual and communal levels, complicating the value assigned autonomy as a virtue and a public or private good. They enable autonomy to signify either a rejection of, or a commitment to, community, depending on which definition is privileged. Insofar as the dignity and very definition of the person who is the subject of human rights depends on her or his recognition as an autonomy-bearing individual, then human rights discourse may be seen as a logical extension of liberal theories of autonomy. But insofar as the autonomy of this individual, or of this person's investment in an indigenous or minority collective autonomy, might be seen as a threat to the state, then we seem to be presented with contending autonomies. The priority of state autonomy over other forms of collective autonomy itself depends in liberal democracies on the primary notion of individual autonomy. Human rights become an issue when a state is seen to override autonomy of the individual. The concept of cultural rights further complicates these relations. Are these too to be seen as 
deriving from individual human rights or from alternative notions of collective communal autonomy that do not necessarily depend on separating the individual from the community in the same kind of way?

For those of us working on what became the book, Renegotiating Community (Brydon and Coleman, 2008), these questions were further complicated by our awareness that concepts of community challenged assumptions about both nation-state and individual autonomy. The larger team began with most participants working within social science frameworks assuming that autonomy, understood as self-determination or self-government, was a value worth endorsing and that the kind of autonomy that concerned our project was primarily the province of the nation-state in an international system of nation-states. This was the kind of autonomy that conventional wisdom suggested globalization was undermining. Humanists among us were more inclined to privilege individual autonomy as the model on which state autonomy then depended, or at least following Habermas saw the two forms of autonomy codetermining each other. Surprisingly, globalization studies has addressed much less attention to this interaction between forms of autonomy than it has to nation-state autonomy alone. Individual autonomy seems to be the province of philosophers, feminists, and political theorists whose work enters the globalization discussions only fitfully, if at all. In the same vein, philosophical considerations of autonomy tend to focus on its relation to liberalism (Christman and Anderson, 2005), feminism (Mackenzie and Stoljar, 2000), or bioethics (Owen et al., 2009). Renegotiating Community (Brydon and Coleman, 2008) brought these different discourses together but more work needs to be done.

Our text wrestled, in part, with the challenges posed to liberal theories of autonomy by feminist and postcolonial critique. These cluster around two linked perceptions of how autonomy functions from these perspectives. First, autonomy operates as a hierarchical concept privileging some at the expense of others by separating people assumed to be capable of exercising autonomy from those excluded from such potential, traditionally women, children, slaves, the disabled, and indigenous and other colonized peoples. Identifying these hierarchical dimensions of the autonomy-concept throws into question liberal autonomy's self-characterization as a democratic and potentially egalitarian concept. Second, and following upon the first observation, autonomy is a Western concept posing as a universal and employed to discipline and shape subjectivities into compliance with the progress of modern capitalism. Seen from this perspective, liberal autonomy's self-characterization as a liberating concept is problematized by recognition of its apparently in-built culture-specific and sometimes oppressive dimensions.

Eventually, the volume worked through some of these interactions through a series of case studies, which collectively came to question commonsense assumptions that globalization was uniformly threatening community autonomy. Although threats are certainly there, authors also recognize that many understandings of what community means and how it might operate are undergoing revision. Along with these revisions come challenges to communitarian and neoliberal assumptions about the autonomy of the individual within the community and about the nature of community autonomy itself. Our study focuses on sub-state or trans-state communities and their internal and external relations. We do not consider questions of national communities and nation-state autonomy nor of claims to secession made by national minorities. These issues are addressed to some degree, however, in a companion volume in the Globalization and Autonomy Series on Unsettled Legitimacy (Bernstein and Coleman, 2009). A few of the community book's chapters study indigenous communities seeking and exercising autonomy within Canadian and Australian settler colony contexts. These chapters are concerned with local 
governance and natural resource management, the challenges posed to community autonomy by globalizing processes, and the opportunities they might potentially provide.

This project led me to think more deeply about the tensions between my personal, feminist investment in autonomy as a value and a virtue and my postcolonial and feminist awareness of what Lorraine Code (2000) terms various 'perversions of autonomy'. My literary-critical bias toward privileging individual subjectivities and their quests for autonomy (albeit within relational situations) has yielded to a greater interest in the institutional arrangements in which such subjectivities are formed and through which they might exercise collective forms of autonomy. If autonomy is central to how we understand democracy, then how may democratic practices adjudicate competing autonomy claims, whether collective or individual? Renegotiating Community did not set out to answer these questions but they emerge, to varying degrees, from some of the circumstances we analyzed. I wish to investigate them more closely now.

In the context of such questions, then, this article focuses on nation-state autonomy in relation to globalizing pressures to respect human rights (rights to autonomy of the person and the right to self-government of ethno-cultural homeland and indigenous nations, a right that is also claimed in the name of autonomy). Most states currently have considerable autonomy (understood as independence) in controlling their response to international pressures in these areas. That kind of nation-state autonomy is often defended in the name of respect for internal nation-state sovereignty. Robert Jackson defines sovereignty as 'a legal institution that authenticates a political order based on independent states whose governments are the principal authorities both domestically and internationally' (1999, p. 432). In such a definition, internal sovereignty indicates that domestically there is only one authority - the state. External sovereignty indicates the system in which states recognize each other as sovereign in these internal affairs (Ibid., p. 433). However, globalization complicates these distinctions. Jackson notes that the modus operandi of sovereignty has been challenged before and has changed as a result (Ibid. p. 434) while defending the viability of the institution in current times. Notably, in defending what he sees as the core values of sovereignty, the state and the international order of states remain constant (Ibid., p. 454). He concludes: 'Sovereignty is an institutional expression of the freedom of groups politically organized as states' (Ibid., p. 455). Others are beginning to question the value of this institution of sovereignty for individual human beings and groups not politically organized as states. Their questioning often relies on appeals to justice and autonomy.

Catherine Dauvergne (2008) identifies nation-state sovereignty in respect to the defense of national borders as one of the key places where the contradictions of globalization may be most clearly observed. Noting that 'refugee law is an exception to the general rule that sovereign states are free to decide who crosses their borders' (2008, p. 62), she deplores the many efforts of states to constrain this law so that 'human rights norms have done little to assist illegal migrants' (Ibid., p. 21). Given this situation, in which 'sovereignty is the uncontested barrier to meaningful, far-reaching reform in this area,' she argues for the need 'to think beyond it, and without it' (Ibid., p. 190). Her insistence that 'decentralizing sovereignty is the only way forward' (Ibid.) issues a radical challenge to globalization theorists to rethink residual investments in sovereignty as a legitimizing concept.

Her argument suggests that with globalization, shifts in how sovereignty is viewed, by states and by civil actors, may be diverging, with implications for legitimacy. States feel pressure to cede some of the autonomy implied by internal nation-state sovereignty in order to have a voice in influencing multilateral attempts to address problems arising from global economic, environmental, and migration flows, among others, but they respond differently to these pressures. As Louis Pauly's article in this issue argues, the sacrifice of fiscal autonomy that may arise 
with the pooled sovereignties made necessary for responding to economic crises makes sense to states as a viable response to globalization. It is harder for states to see any advantage in the claims of No Borders movements advocating the freer movement of peoples and insisting that No One is Illegal. States continue to assert their sovereign rights to control their borders, designate citizenship rights, and declare certain persons 'illegal'. In the face of such intransigency, some respond by pondering the possibility that nation-state sovereignty no longer commands legitimacy. The autonomy of individual persons, including their right to mobility, should not be dependent on recognition by a state.

The situation becomes even more complex when it comes to flows of ideas about autonomies of sub-state and trans-state communities. What Michael Ignatieff (2000) called 'the rights revolution' has come about over the last three decades at least partly in response to globalizing pressures. It is clear that there have been movements at the international level, through the UN, and at the regional level, within the EU, to promote human rights, and as a follow-on of the right to self-determination involved in decolonization, to endorse movements to recognize the autonomy of national minorities and indigenous nations, within so-called multi-nation-states. Decolonization and the break-up of the old Soviet Union appear to have enabled certain substate national groups, national 'homeland minorities', and indigenous peoples to claim autonomy for themselves, either through secession from the state or through internal power-sharing or other shifts in the governance structures of the state. After a brief period of activity in the 1980s and 1990s, possibly culminating in the 2001 Report of the International Commission on Intervention and State Sovereignty (ICISS), which led to the controversial doctrine of the 'Responsibility to Protect', endorsement of those various sub-state autonomy claims (grouped together by Will Kymlicka (2007) in the shorthand designation of multiculturalism) now seems to be in retreat.

By grouping these demands under the heading of multiculturalism, Kymlicka links two concepts that Mahmood Mamdani (2000) implies, in a collection of edited essays called Beyond Rights Talk and Culture Talk, require possible delinking and further unpacking. These concepts_rights and culture-are problematically entangled. What both rights talk and culture talk share is a problematic invocation of autonomy, in its varied usages, which can easily lead to contending autonomies whose claims require adjudicating within the dynamic interaction of law and politics (Mamdani, 2000, p. 13). While recognizing the need to understand culture as processual rather than fixed, Sally Engle Merry exemplifies a tendency within much human rights discourse to problematize culture while leaving rights talk intact. She explains: 'There is a critical need for conceptual clarification of culture in human rights practice. Insofar as human rights relies on an essentialized model of culture, it does not take advantage of the potential of local cultural practices for change' (2006, p. 11). To be effectively tapped, that potential, she argues, needs to be translated from the international sphere into the local vernacular. Like Kymlicka, however, she sees that process of translation as moving from the Western human rights universal into the localized context. She does not seem to question the assumptions about autonomy built into rights talk. Merry writes: 'Human rights ideas and feminist ideas are appropriated by national elites and middle-level social activists and translated into local terms... . The case studies suggest it is layered over other frameworks, such as fair treatment by kinsmen' (Ibid., p. 219). She continues: 'But translation does not mean transformation. Despite changes in the cultural phrasing of human rights ideas and the structural conditions of interventions, the underlying assumptions of person and action remain the same. Human rights are part of a distinctive modernist vision of the good and just society that emphasizes autonomy, choice, equality, secularism, and protection of the body' (Ibid., p. 220). In opposition to her view 
that 'translation does not mean transformation', we would have to put the vast majority of translation theorists within the field of translation studies, who argue that translation inevitably involves a degree of transformation. Here may be where many frictions lie. To the extent that autonomy was central to the 'political rationalities' through which colonial projects were constructed, and remains central to much democratic theory today, then postcolonial theorist David Scott wonders whether postcolonial thinkers should be 'obliged to affirm autonomy as the most desirable form of human being?' (1999, pp. 154-155).

Certainly, individual and sub-state group autonomy demands greatly complicate understandings of both national and nation-state autonomy as values that many think globalization is bringing to crisis in current times. Immigration and population mobilities further complicate this picture, as does the resurgence of religion as a force on the global stage. Globalization theorists point to the increasing influence of diasporic groups within and beyond the nation-state (through remittances to the country of origin, contributions to the economy of the 'host' state, the expansion of the global care economy, complications of citizenship through the increase in holders of dual and multiple citizenships, the brain rotation of elites, demands for cultural and religious accommodation, etc.). These developments require renewed attention to what both belonging and immigration mean for the nation-state as an imagined, collectively autonomous, community. These political and subjective questions focus on the meaning of the value of autonomy within a global system, where the functions of citizen and state are changing, and where the value of nation-state sovereignty is being challenged, both theoretically and in practice, as the primordial position of state autonomy declines relative to other collective and individual autonomies.

The reality is that multi-nation states are the global norm but the ideal nation-state, for many people, still seems to be a monocultural, single entity. This thinking often extends to attitudes to cultural and religious communities within the nation-state, as noted, and deplored, by Margaret Wetherell (2008) in an article about the gaps in assumptions separating academic research on these matters from political statements and policies in the United Kingdom. Theorists of autonomy need to rework this unbalanced relation between ideal conceptions and actual situations on the ground. Within the current tilt toward privileging the ideal, state sovereignty seems to overrule multiple national autonomies. If the supreme power of authority rests with the nation-state, conceived as a singular unit, then it is free to ignore the collective autonomy of its minority subjects, as it sees fit. From the sovereignist perspective, the autonomy of the state is often theorized as something that cannot be shared; if it is fragmented, then social cohesion is thought to be at risk. Advocates of strong forms of social cohesion see local demands of national minorities and the global movements of people as a threat to nation-state autonomy and its ability to maintain security.

I think these advocates are mistaken. They are right to acknowledge the human need to belong to a collectivity larger than the individual but they are wrong to assume this need to belong can only be satisfied in one or two ways: either by living within an essentially monocultural nation-state or by adhering to a set of unchanging values within an essentialized 'culture', which itself exists within a world in which different, identifiably distinct cultures seem doomed to clash. This view of autonomous and competing cultures remains remarkably resilient, engendering renewed critiques by Bhattarcharyya (2008), Dirlik (2008), Parekh (2008), Philips (2007), and Razack (2008). At a political level, sovereignty and autonomy have often been confused yet it remains important to distinguish them if these questions are to be resolved.

In providing a basis for intervening to prevent crimes against humanity undertaken by or within a nation-state, the doctrine of 'Responsibility to Protect' (R2P) arguably challenges the international relations understanding of both internal and external sovereignty in the name of a kind of humanitarian intervention that seems very similar to that used to support imperialist 
benevolence and paternalism in earlier times. To intervene in the name of protecting the autonomy (as the right to self-government) of minority groups within a state that oppresses them might theoretically accord more respect to the ability as well as the right of other peoples to exercise autonomy (thus diminishing accusations of paternalism) but would not make the task of distinguishing between choice and coercion any easier in certain circumstances. Friedman (2003), Philips (2007), and Razack (2008) elaborate this dilemma from different feminist perspectives. Whatever reasons advanced for such invasions of another state's territory, accusations that such decisions are ultimately made on the basis of power relations remain persuasive. Such recognitions, however, do not remove the need to work toward developing normative rules of best conduct within the changing global scene. Charles Kupchan and Adam Mount's article, 'The Autonomy Rule' (2009) appeared too late for full attention here. However, their argument that 'the terms of the next order should be negotiated among all states, be they democratic or not, that provide responsible governance and broadly promote the autonomy and welfare of their citizens' (2009, pp. 9-10), while a useful step forward, still evades the larger questions of definition and contending autonomies with which this article wrestles. A different argument sometimes made for $\mathrm{R} 2 \mathrm{P}$ recognizes a responsibility to support the autonomy, the right to self-government, of those groups within the state whose capacities for self-steering have been abrogated. This argument too can be problematic. Both the initial adoption and the current widespread distrust of this doctrine provide further evidence of why renewed attention to autonomy is more urgent than ever.

In Renegotiating Community, our research team addressed questions that required us to think about globalization, autonomy, and community in tandem. While we sought to recognize the problematization of each term under twentieth-century conditions, we completed the project with a strong sense that ideas about autonomy required further attention. Philosophers might contest Yash Ghai's assertion that 'There is no developed or reliable theory of autonomy; modern but contested justifications revolve around the notion of identity' (2000, p. 4). But this contention seems appropriate for thinking about collective claims in the political sphere. As Ghai indicates, 'The use of autonomy as a species of group rights has changed the character of international law' and, on the domestic level, it is changing ideas about 'the organisation of state, the rationalisations of public power and the homogenising mission of the state' (Ibid., p. 2). These changes are sufficiently powerful to lead Ghai to conclude that 'Autonomy is increasingly becoming the metaphor of our times.' Further support for Ghai's position might be found in Joseph R. Slaughter's argument, emerging from a different disciplinary formation. He claims that 'The movement of the subject from pure subjection to self-regulation describes the plot trajectory of the dominant transition narrative of modernization, which both the Bildungsroman and human rights law take for granted and intensify in their progressive visions of human personality development' (2007, p. 9). In other words, the story of how the autonomy-bearing subject is produced, within the plot of this type of novel and the narrative of human rights law, operates across these different spheres of constitution and regulation to make autonomy central to many of the debates of our times.

Renegotiating Community reaches a conclusion similar to that of Ghai: 'There are limits to generalisations and comparisons, for the concession and operation of autonomy are contingent on several factors - such as history, traditions of governance, the size of territory, the size and number of communities, and internal and external pressures' (2000, p. 4). These variables must be taken into account when assessing the viability and desirability of autonomy claims in different circumstances. Equally important, however, are the different lenses that different disciplinary practices bring to bear on these questions. Too much of the considerable attention given to 
autonomy to date has occurred within disciplinary enclaves, particularly international relations whose very name is invested in a particular historical notion of autonomy, further complicating how the concept is employed and what is meant when autonomy is claimed or granted.

In synthesizing and clarifying these varied usages, scholars and practitioners need to listen to the range of disciplines that have been engaging these issues, within the full geopolitical contexts of different parts of the world. Valuing individual and national autonomy carries different implications for stability and justice in different contexts. Will a strengthened national autonomy aid or hamper poverty reduction, democratic practices, the attainment of social justice, the maintenance of a just peace? These are questions raised by Petra Rethmann in her contribution to this special issue. Many indigenous theorists working within Canadian contexts are developing their own views on these issues. Literary critic Craig Womack's claim that 'Native literary aesthetics must be politicized and that autonomy, self-determination, and sovereignty serve as useful literary concepts' is cited approvingly by Kimberly Rappolo (2008, p. 311). While these concepts recur throughout the volume in which Rappolo's essay appears, their use would benefit from greater definitional clarity and dialogue with related work in other disciplines. Legal scholar James Sakej Henderson (2002) has mounted an influential argument in favor of multiscalar citizenship in his essay 'Sui Generis and Treaty Citizenship'.

According to pollster Michael Adams (2007), Canadians remain largely supportive of Canadian multicultural adjustments although voices of dissent take ammunition for their views from what is happening elsewhere, in Australia and especially in Europe. This is the context in which I view several recent critical books that consider how nation-states are addressing the pressures that come with an increasingly interdependent world. Bhikhu Parekh (2008) and Will Kymlicka (2007) are political theorists seeking to define new principles for managing identity politics and imagining what Parekh calls 'a new politics of identity'. Anne Phillips (2007) and Sherene Razack (2008) are feminist theorists of cultural difference and social policy. Each of the four critique the logic of the clash of civilizations thesis and the forms of culturalism it endorses, while charting different routes through the difficulties such views pose for human rights advocacy within current global conditions.

Phillips and Razack are most valuable for the difficult questions they ask about women's autonomy in an era when women's rights are increasingly being used as an alibi for interfering with their own autonomy as well as that of others: notable here are the invasions of Afghanistan and Iraq and legislative attempts to restrict the autonomy of Muslim women and their ethnocultural groups in the name of a responsibility to protect that is now being applied internally within nation-states with immigrant populations. In analyzing legislation designed to restrict enforced marriages and legislate dress codes, each points to a flawed cultural logic. Muslims are constructed as non-autonomous subjects, coerced by their culture, and incapable of exercising full citizenship in opposition to non-Muslims, who are implicitly recognized as fully autonomous humans capable of free choice. Their arguments complement those of Ratna Kapur (2005), although only Phillips cites her analysis directly. Like Parekh, these writers seek to develop principles of global ethics that might better respect the autonomy of all, while recognizing that autonomy itself as a concept may need to be freed from its anchoring in liberal thinking.

In addressing what she terms the 'culturalization of politics' (2006, pp. 19-24, 151, 167), Wendy Brown notes it operates unevenly across the globe: 'culture is understood to drive Them politically and to lead them to attack our culture, which We are not driven by but which we do cherish and defend' (Ibid., p. 20). In making this case, she cites Mahmoud Mamdani: 'The moderns make culture and are its masters; the premoderns are said to be but conduits' (cited in Ibid.). This is the logic that the anthropologist Christoph Bruman calls 
'culturalism', defined as a form of 'cultural fundamentalism ... [that] posits the existence of a finite number of distinct cultural heritages in the world, each tied to a specific place of origin' (2005, p. 68). At an international level, this understanding of culture may authorize theses such as Samuel Huntington's 'clash of civilizations' while within the nation-state it may legitimate policies of biculturalism and multiculturalism. Bruman's definition is employed and expanded upon in a range of anthropological, educational, feminist multicultural, and postcolonial studies, which are, however, not always aware of one another (Kapur, 2005; Menezes and Andreotti, in press; Nakata, 2007; Phillips, 2007; Razack, 2008). For such critics, culturalist modes of thinking have been informed by imperialism to such an extent that they inscribe a differential relation to culture at the very heart of distinctions between those seen as fully human and civilized and those who remain the victims of their culture. This form of culturalism, long linked to the characterizations of indigenous peoples and now increasingly transferred to non-Muslim characterizations of Muslims, has emerged as a particularly dangerous form of thinking in current multicultural debates.

Kymlicka's (2007) Multicultural Odysseys: Navigating the New International Politics of Diversity takes a different tack, addressing nation-state autonomy within the international system from his influential position as an advocate of liberal multiculturalism. Kymlicka examines the autonomy claims of three broad categories of community on the nation-states they occupy: indigenous peoples, territorially based 'homeland minorities,' and to a much lesser extent, immigrant groups. He concludes that the conditions enabling Western transitions to more complex forms of federal power-sharing, such as indigenous self-government, formal recognition and distribution of self-governing powers to sub-state minorities, and other forms of minority accommodations, are not present for post-communist or postcolonial states. A possible exception is in parts of Latin America, where he sees indigenous groups gaining some recognition for their autonomy claims. The reasons for these state resistances to minority autonomy demands result from historical and geopolitical conditions that make acceding to such demands a much more risky proposition for state security. Nonetheless, if local demands for forms of sub-state autonomy cannot be met, he sees problems for the autonomy of postcommunist and postcolonial states in the future. These problems, in turn, may threaten the stability of the global system. Instead of devising means to reduce these risks, he argues, international intergovernmental organizations (IOs), the EU, and the United Nations appear to be retreating from a short, earlier period of promoting minority rights and what Kymlicka calls 'ethnocultural justice' in these constituencies. As an advocate of the global diffusion of liberal multiculturalism, along what seems to be largely a Canadian model, Kymlicka deplores this retreat and the failure of these bodies to confront these dilemmas head-on.

Kymlicka argues that multiculturalism is a liberal set of concepts and policies designed to address the rights claims of these three groups, claims that have been globally diffused as both a political discourse and a set of codified legal norms. He concentrates attention on those IOs that work at regional or global levels to promote models for governing diversity and on the deep divisions within these as to the merits of international norms of minority rights and the control of how they might develop. He contends that these IOs have considerable autonomy in defining their positions and they 'have often exercised their autonomy in ways that box them into moral conundrums and political dead-ends' (2007, p. 13). Therefore, he sees the 'commitment to multiculturalism and minority rights as "now deeply institutionalized within the international community' (Ibid., p. 296), but in such weakly theorized forms as to require serious rethinking if the project of internationalizing minority rights is to be put 'on a more stable footing, conceptually and politically' (Ibid., p. 297). In particular, he sees a need 
to distinguish more clearly between homeland national minorities and indigenous nations. This rethinking matters, in part, because of its implications for autonomy, democracy, and citizenization.

Here is where the chief interest of Kymlicka's book may lie for globalization researchers. The problem as he sees it is that 'Minorities around the world are demanding greater respect and recognition ... Yet many post-communist and post-colonial states have difficulty responding to these claims ...' (Ibid., p. 295). As an advocate of the global diffusion of liberal multiculturalism, Kymlicka seeks to understand resistances to these policies and to elaborate the conditions necessary for their acceptance. While acknowledging that these IOs seldom use the term multiculturalism themselves, Kymlicka employs it as an umbrella term to cover a range of policies that go beyond the protection of individual rights to 'extend some level of public recognition and support for ethnocultural minorities to maintain and express their distinct identities and practices' (Ibid., p. 16). Here is where I think the community/culture conflation could be usefully unpacked. Nonetheless, he also recognizes that 'we need to get a range of contending approaches on the table, so that we can systematically evaluate their respective strengths and weaknesses' (Ibid., p. 298). This would need to be an international and interdisciplinary conversation attending to at least the following three questions in his estimation. First, how do we clarify the categories of minority rights? Second, what are the preconditions for minority rights? And third, what is the forum or arena for minority rights? (Ibid., p. 299). Concepts of what is meant by rights and understandings of why they matter, ideas about what constitutes a minority, and why minority rights are necessary, are not up for questioning in this framing of the issues.

Recognizing the inadequacy of current scholarship in addressing his questions, Kymlicka calls for 'a collaborative effort, drawing on the input of different academic disciplines, as well as different types of state and non-state actors, from different regions of the world' (Ibid., p. 298). He sees a base for such a project in the work of three groups: 'normative political theorists of the ideals and best practices of liberal multiculturalism, derived primarily from the experience of the consolidated Western democracies'; political scientists providing casespecific accounts of 'conflict resolution techniques in weak or divided societies'; and international lawyers working on minority rights. To fill the lack of systematic research on these questions, these academic groups need to come together to pool their knowledge (Ibid., pp. 298-299).

From my perspective, Kymlicka presents too narrowly based a project to successfully address these questions. Many other disciplines have worked on these questions and within different frames of reference. In a footnote, he acknowledges: 'While liberal multiculturalism has been the most influential normative framework at the international level to date, we should not exclude the possibility that some other normative political theory can provide a better set of conceptual tools for addressing these dilemmas. It would indeed be very helpful if we had, say, a Buddhist or Islamic theory of international minority rights ... To my knowledge, no such theories exist ...' (Ibid., p. 299, fn. 1). This comment raises an interesting conundrum. To the extent that Western theories may well be the only locally generated theories to posit universal systems based on their understandings of the world, such a generalization may possibly prove true although it seems unlikely. On the other hand, other cultures have generated their own debates within their own theorizations of appropriate relations to be established in relation to self, autonomy, and community. These are now complicating cross-cultural and comparative analyses of ethics and feeding into theorizations of global ethics, as Kymlicka knows. Yet the problem persists in his jointly edited book The Globalization of Ethics (Sullivan and Kymlicka, 
2007), which displays a tendency to see these other systems as monolithic, autonomous in the sense of self-contained, and unriven by internal debates. There are further problems with this footnote. Normative political theory may prove unable to provide the set of conceptual tools adequate to address globalization. In referring to Buddhist or Islamic theory, Kymlicka seems to imply that these categories are not themselves disputed; that religious categories are to be counterposed to liberalism; and that the cultural foundations of these religions would have a conception of individual autonomy that leads to rights thinking, or that if they did not, then they could not usefully provide a foundation for new global arrangements. In other words, while appearing to acknowledge the possibility of a dialogue on equal terms, this statement can only see potential alternative systems within a Western frame and is only prepared to engage them on Western-centric terms.

In keeping with this approach, Kymlicka starts his inquiry in Multicultural Odysseys from the liberal multiculturalist perspective, rather than from an acceptance that the broader goals this approach might realize-increased (and possibly redefined) autonomy, democratization, peace, justice-could be accomplished by other means. Kymlicka recognizes that 'the status quo is not only imperfect, but in fact unstable' (Ibid., p. 316) but his suggestions for reconceptualizing the issues remain narrow. The range of disciplinary expertise and cultural perspectives he suggests remains circumscribed and he takes insufficient account of the critiques of multiculturalism and the legal decisions in which these categories increasingly play a role that are raised by theorists sympathetic to autonomy demands such as Phillips and Razack. In the terms provided by Santos, Nunes, and Meneses (2007, p. xxiii), Kymlicka's form of multiculturalism expresses 'the cultural logic of multinational or global capitalism', a logic they contrast with 'emancipatory versions of multiculturalism' working out of recognitions of "overlapping territories" and "intertwined histories", which call 'for a complex procedure of reciprocal and horizontal translation rather than for a general theory' (Ibid., p. xxv). The extensive range of work undertaken on autonomy and rights discourses, and on globalization, community, and culture, from perspectives derived from a range of perspectival, ideological, theoretical, and geopolitical experiences, needs to be brought into dialogue with the kinds of studies privileged by Kymlicka, if a genuine dialogue is to be begun.

In this article, I have addressed the maneuvering space globalization affords communities and states to chart their own paths within global systems and the implications of how culturally based autonomy demands (made on behalf of groups and individuals) are currently being received. I raise the question of how disciplinary autonomies shape understanding of culture and autonomy, because our questions and conclusions depend on the assumptions we begin with - and because the frames themselves are changing. For this reason, scholars need always attend to the kinds of demands that globalization makes on knowledge production, including the pressures it exerts on disciplinary autonomies and the demands it makes for inter- and cross-disciplinary investigation. This article has raised two dimensions of the globalization-autonomy relation: first, how it is changing understandings of cultural and political diversity, especially the rights claims of autonomy-seeking groups, foremost among these indigenous, ethnocultural communities, and women; and second, its implications for the conduct and dissemination of research. Kymlicka is highly critical of educational initiatives undertaken internationally to promote understanding of homeland minority nation autonomy as well as cognizant of the need for more systematic and large-scale research. Likewise, Razack raises the question of how to identify and implement appropriate educational and pedagogical initiatives to challenge inequitable culturalist thinking but without providing any answers beyond deconstructing the faulty logic of culturalist thinking. The challenge is clear but the way forward will require closer attention to the 
framing imaginaries within which communities, including academic communities, are constituted and the autonomy claims they are prepared to recognize.

\section{Acknowledgments}

This article has been deeply influenced by the 'Globalization and Autonomy' collaboration led by William Coleman and supported by a Major Collaborative Research Initiative grant from the Social Sciences and Humanities Research Council of Canada. It links to William Coleman and Diana Brydon (eds) Renegotiating Community: Interdisciplinary Perspectives, Global Contexts (Vancouver, BC: University of British Columbia Press, 2008). It also draws on research into national and global imaginaries supported by the Canada Research Chairs Program. An earlier version of the paper was delivered at the Globalization Studies Network meetings at the Centre for International Governance Innovation, University of Waterloo, in August 2008.

\section{References}

Adams, M., with A. Langstaff (2007) Unlikely Utopia: The Surprising Triumph of Canadian Pluralism (Toronto: Viking Canada).

Benhabib, S. (ed.) (2006) The philosophical foundations of cosmopolitan norms, in S. Benhabib Another Cosmopolitanism, R. Post (ed.) with responses by J. Waldron, B. Honig, \& W. Kymlicka, The Berkeley Tanner Lectures (Oxford: Oxford University Press), pp. 13-44.

Bernstein, S. \& Coleman, W. (eds) (2009) Unsettled Legitimacy: Political Community, Power, and Authority in a Global Era (Vancouver, BC: University of British Columbia Press).

Bhattarcharyya, G. (2008) Dangerous Brown Men: Exploiting Sex, Violence and Feminism in the War on Terror (London: Zed).

Brink, B. van den (2005) Liberalism without agreement: political autonomy and agonistic citizenship, in J. Christman \& J. Anderson (eds) Autonomy and the Challenges to Liberalism (Cambridge: Cambridge University Press), pp. 245-271.

Brown, W. (2006) Regulating Aversion: Tolerance in the Age of Identity and Empire (Princeton: Princeton University Press).

Bruman, C. (2005) Writing for culture: why a successful concept should not be discarded, in A. Muller (ed.) Concepts of Culture: Art, Politics and Society (Calgary: University of Calgary Press), pp. 43-77.

Brydon, D. \& Coleman, W. D. (eds) (2008) Renegotiating Community: Interdisciplinary Perspectives, Global Contexts (Vancouver: University of British Columbia Press).

Christman, J. \& Anderson, J. (eds) (2005) Autonomy and the Challenges to Liberalism: New Essays (Cambridge: Cambridge University Press).

Code, L. (2000) The perversion of autonomy and the subjection of women: discourses of social advocacy at century's end, in C. Mackenzie \& N. Stoljar (eds) Relational Autonomy: Feminist Perspectives on Autonomy, Agency, and the Social Self (Oxford: Oxford University Press), pp. 181-209.

Dauvergne, C. (2008) Making People Illegal: What Globalization Means for Migration and Law (Cambridge: Cambridge University Press).

Dirlik, A. (2008) Race talk, race, and contemporary racism, PMLA, 123(5), pp. 1363-1379.

Fraser, N. (2007) Reframing justice in a globalizing world, in J. Goodman \& P. James (eds) Nationalism and Global Solidarities: Alternative Projections to Neoliberal Globalisation (London: Routledge), pp. 168-186.

Friedman, M. (2003) Autonomy, Gender, Politics (Oxford: Oxford University Press).

Ghai, Y. (2000) Ethnicity and autonomy: a framework for analysis, in Y. Ghai (ed.) (2000) Autonomy and Ethnicity: Negotiating Competing Claims in Multi-ethnic States (Cambridge: Cambridge University Press), pp. 1-26.

Henderson, J. S. (2002) Sui generis and treaty citizenship, Citizenship Studies, 6(4), pp. 415-440.

Honig, B. (2006) Another cosmopolitanism? Law and politics in the New Europe, in S. Benhabib Another Cosmopolitanism, R. Post (ed.) with responses by J. Waldron, B. Honig, \& W. Kymlicka, The Berkeley Tanner Lectures (Oxford: Oxford University Press), pp. 102-127.

Ignatieff, M. (2000) The Rights Revolution (Toronto: Anansi). 


\section{2}

D. Brydon

International Commission on Intervention and State Sovereignty (ICISS) (2001) The Responsibility to Protect, Report of the International Commission on Intervention and State Sovereignty (Ottawa: International Development Research Centre), http://www.iciss.ca/report-en.asp

Jackson, R. (1999) Sovereignty in world politics: a glance at the conceptual and historical landscape, Political Studies, 97, pp. 431-456.

Kapur, R. (2005) Erotic Justice: Law and the New Politics of Postcolonialism (London: Glasshouse).

Kupchan, C. \& Mount, A. (2009) The autonomy rule, Democracy: A Journal of Ideas, 12, pp. 8-21. http://www. democracyjournal.org

Kymlicka, W. (2007) Multicultural Odysseys: Navigating the New International Politics of Diversity (Oxford: Oxford University Press).

Mackenzie, C. \& Stoljar, N. (eds) (2000) Relational Autonomy: Feminist Perspectives on Autonomy, Agency, and the Social Self (Oxford: Oxford University Press).

Mamdani, M. (ed.) (2000) Beyond Rights Talk and Culture Talk: Comparative Essays on the Politics of Rights and Culture (New York: St. Martin's Press).

Menezes, L. M. de Souza \& Andreotti, V. (in press) Culturalism, difference and pedagogy: lessons from indigenous education in Brazil, in J. Lavia \& M. Moore (eds) Cross-Cultural Perspectives on Policy and Practice: Decolonizing Community Contexts (London: Routledge).

Merry, S. E. (2006) Human Rights and Gender Violence: Translating International Law into Local Justice (Chicago: University of Chicago Press).

Nakata, M. (2007) Disciplining the Savages Savaging the Disciplines (Canberra: Aboriginal Studies Press).

Owen, G. S., Freyenhagen, F., Richardson, G., \& Hotopf, M. (2009) Mental capacity and decisional autonomy: an interdisciplinary challenge, Inquiry, 52(1), pp. 79-107.

Parekh, B. (2008) A New Politics of Identity: Political Principles for an Interdependent World (London: Palgrave Macmillan).

Phillips, A. (2007) Multiculturalism Without Culture (Princeton: Princeton University Press).

Rappolo, K. (2008) Samson Occom as writing instructor: the search for an intertribal rhetoric, in C. S. Womack, D. Heath Justice \& C. B. Teuton (eds) Reasoning Together: The Native Critics Collective (Norman: University of Oklahoma Press), pp. 303-324.

Razack, S. H. (2008) Casting Out: The Eviction of Muslims From Western Law and Politics (Toronto: University of Toronto Press).

Santos, B. de Sousa, Nunes, J. A., \& Meneses, M. P. (2007) Introduction: opening up the canon of knowledge and recognition of difference, in B. de Sousa Santos (ed.) Another Knowledge is Possible: Beyond Northern Epistemologies (London: Verso), pp. vii-xvix

Scott, D. (1999) Refashioning Futures: Criticism After Postcoloniality (Princeton: Princeton University Press).

Slaughter, J. R. (2007) Human Rights Inc. The World Novel, Narrative Form, and International Law (New York: Fordham).

Sullivan, W. \& Kymlicka, W. (eds) (2007) The Globalization of Human Rights: Religious and Secular Perspectives (Cambridge: Cambridge University Press).

Wetherell, M. (2008) Speaking to power: Tony Blair, complex multicultures and fragile white English identities, Critical Social Policy, 28(3), pp. 299-319.

Diana Brydon is Canada Research Chair in Globalization and Cultural Studies at the University of Manitoba. She has published books on postcolonial theory and literature, currently serves as a member of the convening group for 'Building Global Democracy' (http://www. buildingglobaldemocracy.org), and is conducting individual research on global and national imaginaries. 
Copyright of Globalizations is the property of Routledge and its content may not be copied or emailed to multiple sites or posted to a listserv without the copyright holder's express written permission. However, users may print, download, or email articles for individual use. 